\title{
The epistemological construction of transsexuality: the science, nursing and common sense
}

\author{
A construção epistemológica da transexualidade: a ciência, enfermagem e o senso comum
} La construcción epistemológica de la transexualidad: la ciencia, enfermería y el senso común

\author{
Janaina Pinto Janini ${ }^{1}(\mathbb{C}$ \\ Rosangela da Silva Santos ${ }^{1}$ (i) \\ Lívia Fajin de Mello dos Santos ${ }^{2}$ (i) \\ Viviane de Melo Souza ${ }^{1}$ (D)
}

1. Universidade do Estado do Rio de Janeiro.

Rio de Janeiro, RJ, Brasil.

2. Associação Brasileira de Ensino

Universitário. Belford Roxo, RJ, Brasil.
Corresponding author Janaina Pinto Janini.

E-mail: jjanini40@gmail.com

Submitted on $11 / 28 / 2018$.

Accepted on 05/02/2019.

DOI: 10.1590/2177-9465-EAN-2018-0345

\section{Abstract}

Objective: To know the common sense of transsexual women in reaction to the transsexual process and to discuss the epistemological construction about the transsexuality and nursing in this process. Method: Qualitative research, carried out between May and June 2017, with 90 transsexual women attending a specialized center. Results: The common sense of the interviewees evidenced the transsexuality as an identity issue and not a disease, barriers to attendance in health demands and absence of the nursing professional. Discussion: The epistemological construction of the transsexuality takes place through science, which instrumentalized the Transsexual Process Policy and does not have the knowledge presented by the common sense of the users. Conclusion and implications for nursing practice: Science has a role to create order and practices from the refinement of common sense, but does not use the common sense of transsexual women in the epistemological construction of transsexuality, which compromises care and reinforces stereotyped and pathological character by health professionals. Science has the power to validate common sense, sedimenting the care to transsexual women, especially nursing practice. Nursing has the challenge of understanding issues related to transsexuality by articulating common sense with scientific knowledge.

Keywords: Transsexual people; Science; Knowledge; Nursing; Gender; Identity.

\section{REsUMO}

Objetivo: Conhecer o senso comum de mulheres transexuais em reação ao processo transexualizador e discutir a construção epistemológica acerca da transexualidade e da enfermagem nesse processo. Método: Pesquisa qualitativa, realizada entre maio e junho de 2017, com 90 mulheres transexuais atendidas em centro especializado. Resultados: $O$ senso comum das entrevistadas evidenciou a transexualidade como uma questão identitária e não uma doença, entraves no atendimento em demandas de saúde e ausência do profissional de enfermagem. Discussão: A construção epistemológica da transexualidade, se dá por meio da ciência, que instrumentalizou a Política do Processo Transexualizador e não dispõe de conhecimento apresentado pelo senso comum das usuárias. Conclusão e implicações para a prática de enfermagem: A ciência tem um papel de criar ordem e práticas a partir do refinamento do senso comum, mas não utiliza o senso comum das mulheres transexuais na construção epistemológica da transexualidade, que compromete a assistência e reforça o caráter estereotipado e patológico pelos profissionais de saúde. A ciência tem o poder de validar o senso comum, sedimentando a assistência às mulheres transexuais, em especial, a prática de enfermagem. A enfermagem tem o desafio de compreender as questões relacionadas à transexualidade articulando o senso comum com o saber científico.

Palavras-chave: Pessoas transexuais; Ciência; Conhecimento; Enfermagem; Gênero; Identidade.

\section{Resumen}

Objetivo: Conocer el sentido común de mujeres transexuales en reacción al proceso transexualizador y discutir la construcción epistemológica acerca de la transexualidad y de la enfermería en ese proceso. Método: Investigación cualitativa, realizada entre mayo y junio de 2017, con 90 mujeres transexuales atendidas en centro especializado. Resultados: El sentido común de las entrevistadas evidenció la transexualidad como una cuestión identitaria y no una enfermedad, trabas en la atención en demandas de salud y ausencia del profesional de enfermería. Discusión: La construcción epistemológica de la transexualidad, se da por medio de la ciencia, que instrumentalizó la Política del Proceso Transexualizador y no dispone de conocimiento presentado por el sentido común de las usuarias. Conclusión e implicaciones para la práctica de enfermería: La ciencia tiene un papel de crear orden y prácticas a partir del refinamiento del sentido común, pero no utiliza el sentido común de las mujeres transxuales en la construcción epistemológica de la transexualidad, que compromete la asistencia y refuerza el carácter estereotipado y patológico por los profesionales de salud. La ciencia tiene el poder de validar el sentido común, sedimentando la asistencia a las mujeres transexuales, en especial, la práctica de enfermería. La enfermería tiene el desafío de comprender las cuestiones relacionadas a la transexualidad articulando el sentido común con el saber científico.

Palabras clave: Personas transexuales; La ciencia; Conocimiento; Género; Identidad. 


\section{INTRODUCTION}

The science has a crucial role in society and helps to change of opinions and knowledge, with the reconstruction of new codes from the common sense constituted in the society. ${ }^{1}$ The category of gender represents a code, which undergoes the action of the science in its measurement and delimits dichotomous biological and identifying aspects of masculinity and of femininity between the genders. ${ }^{2}$ These delimitations permeate a regulatory process of the bodies, which determine standardizers patterns for all members of the society that, que, imbued with common sense, lead to practices, behaviors and identities that define as woman or man. ${ }^{3}$

The transsexuality is a counterpoint to these norms, because it does not match the social characterization of the bodies and the roles of the women understood as feminine, as well as, for the men, the characteristics understood as masculine, by using the terminology 'identity of gender. ${ }^{4}$ The transsexuality is represented by people an identity of gender is opposite to the sex of the birth registration. . $^{5,3,6}$

Hereinafter, the construction of the transsexuality is emphasized in the health area, used by the society to regulate the identifying questions of gender, with a 'supposed scientific base constructed', designed as the inadequacy between the biological sex and the identity of gender. ${ }^{7}$ Defined by the CID10 as a gender identity disorder, it gains a disease dimension and becomes a phenomenon understood epistemically within the health context. For the purposes of giving resolution to the physical adequacy with the identity of gender, by drug and surgical interventions, the Transsexualizing Process was established as a way of subsidizing this practice. ${ }^{6-8}$

The Transsexualizing Process constitutes a public health policy where, through the Brazilian Unified Health System - SUS, institutions offer specialized services for the physical adequacy of transsexual persons. It's regulated by decree MS/GM 2803 of $2018^{6}$, that offer multidisciplinary support, where the nurse is inserted, which requires scientific and technical knowledge to offer a care of quality. In this the nursing professional must provide a qualified care, with welcoming of the transsexual person in the health services without discriminating it, breaking with the stigmatized view. Thus, the key role of nursing for the transsexual public is to ensure a worthy and humanized care, from the basic attention of health, to intermediate and high complexity, promoting fundamental actions to promote integral health in an effective and of qualified way. ${ }^{9}$

The Transsexualizer process has the technologies and knowledge offered by the science, in the care to the transsexual person. ${ }^{10}$ However, a science cannot be established without taking the health needs of a particular group into consideration, since the science nothing more is than "refined and disciplined common sense". ${ }^{11: 19}$ Giving voice to the transsexual persons is showed as an important source of information for building the health care, with the externalization of the common sense of the same about such questions and their true needs to be addressed.
The philosopher Rubem Alves points out the relevance of the understanding of the questions that involve the common sense for better understanding of what is the science. From the immersion in a problem it can be understood the common sense. At the proportion that situations arise that trigger questionings, the relevance of the thinking begins, the search for solutions and the link between the answer with the nature and with the society. ${ }^{11}$

That way, at understanding epistemologically the construction of the transsexuality, by the look of the transsexual persons attended, in the health context, by the Policy of the Transsexualizer Process, it offers interfaces to be discussed for the construction of the adequate nursing practice to this clientele. ${ }^{12}$ The equalization of information of this population linked to the scientific findings, subsidized in a philosophical theoretical support help construct the knowledge, including nursing, providing a differentiated look at the practice. ${ }^{13-14}$

In Brazil, there are lack of information about the transsexual persons both in the academic environment, ${ }^{15}$ and in the care that signals the need of theoretical deepening about. So, there are some questions: Which is the common sense of the transsexual women regarding the transsexuality and the transsexualizer process? How the common sense of the transsexual women can subsidize the construction of the knowledge for the science and for the nursing?

This study aimed to know the common sense of transsexual women regarding the transsexualizer process and to discuss the epistemological construction about the transsexuality and the nursing in this process.

\section{METHOD}

Exploratory study, of qualitative nature. A cutting of the research entitled 'Social (re) insertion of the transsexual person: social questions and of health', which aimed at analyzing the social reinsertion process, from the transsexual persons' experiences.

The more extended study was approved by the Research Ethics Committee through the opinion CAAE: $64975517,9,0000,5266$, and met the guidelines required by the Resolution no. 466/12 that regulates researches involving human beings. ${ }^{16}$

The research scenario was a public institution of assistance to health, located in the Rio de Janeiro municipality that implements the Policy of the Transsexualizer Process. The unit provides specific services to the attendance on Endocrinology and Diabetes, including the hormonal treatment to transsexual persons registered.

The unit in the period of 2017 had the total of 263 transsexual women registered that received periodical consultations with: endocrinologist, psychologist and psychiatrist. The consultations took place on Wednesdays (morning and afternoon) and Thursdays (morning). The initial approach of the researchers with the participants occurred in the waiting room of the outpatient care. In this first contact there was a brief presentation, explanation of the research objective and the invitation to participate in the study. 
The qualitative sampling adopted in the study was intentional, constituted by 90 transsexual women that were consulted in the period of May to June 2017. All invited transsexual women agreed to participate in the research. They were forwarded before the consultation to a reserved room. In this place it was done the reading of the Free and Informed Consent Term (FICT) and later the signature in two copies. The term transsexual women was adopted to define the interviewees who had male biological sex, but with identity of female gender.

The adequacy of the sample size was established based on the principle of the theoretical saturation, where new concepts in the data collection do not arise.${ }^{17}$ Although some questions to be addressed has been saturated rapidly, others were needed for the continuity of the interviews, which justifies the number of participants.

We used an intentional sampling, since the study aimed at choicing the participants with specific characteristics, of the research interest, such as to identify the users'behaviors within the health units and the investigation of marginalized groups to understand how are conduced and the levels of stigma of a certain group.$^{17-18}$

The inclusion criterion for the study was: transsexual women registered in the Public health policy of the Transsexualizer Process that realize the hormonal treatment for physical feminization. The exclusion criterion was transsexual women who had time space disorientation.

After, the semi-structured interview was initiated, composed of 19 questions, being 14 closed and 5 open. The interviews has an average duration of 20 minutes and was used the audio recordings at collecting the data.

The interviews transcriptions occurred simultaneously to the collection. In order to preserve the participants' s identity, the interviewees' reports were represented by letter "e" added of a numerical sequence for organization and identification of the same.

In possession of the transcribed material, it was carried out the content analysis of Minayo as a way of the data treatment. The rite of this process occurred in three phases: data preanalysis, material exploration and data treatment. ${ }^{19} \mathrm{At}$ the end of the phases it was identified the category: science and common sense: interfaces in the care to the transsexual and the nursing.

The analysis of the category anchored itself in reference of the philosophy of the science of Rubem Alves, where is discussed, in a wide way, the triad composed between the science, the construction of the scientific knowledge and the common sense. ${ }^{11}$ Due to the specificity and the need of the theoretical immersion and understanding about the thematic, and also other references were used in the gender area and nursing.

\section{RESULTS}

The interviewees had age group between 18 and 59 years, among them: 24 with incomplete elementary level, 13 in complete elementary level, 17 in incomplete secondary level, 32 in complete secondary level and 4 in incomplete high school.
Only 21 of them worked, being 15 in informal employment. Of these, 11 develop professional activities considered socially as feminine: as hairstylist $(n=2)$, manicure $(n=1)$, make-up artist $(n=1)$, dressmaker $(n=1)$, nursing technician $(n=1)$, cleaning professional $(n=2)$, receptionist $(n=1)$ and teacher $(n=2)$.

With regard to the understanding about the identity of gender, all interviewees $(n=90)$ described the transsexuality as a way of seeing itself and perceiving itself and not as a mental disease, contradicting the international classification of disease that support the Policy of transsexualizer process. The use of the word 'normal' arises in 79 speeches of transsexual women interviewees. When asked about the female gender identity, 32 of them asked the reason of the society understand the transsexuality as an abject or non-normative.

[...] I do not see me as ill...since I was small I'm in this manner... I'm feel a girl....(sigh). In different countries the trans are seen as normal, I do not understand why here no. (e57).

[...] I thanks today for having the opportunity of being attended as a woman in the hospital, but I would not like to be as a disturb (e1).

With regard to the Transsexualizer Process, all the interviewees $(n=90)$ referred the benefit of the gratuity to be submitted to the physical change:

[...] I took medicine on my own to change my body, but I will never get making the surgery (e29).

[...] It was a great gain for the category to do the free treatment. I'm attended by excellence professionals (e46).

The gratuity of the treatment in the Transsexualizer process is considered as an easiness $(n=10)$ by transsexual women due to the lack of financial resource to pay for the hormonal and surgical treatment, as well as the acceptance of the transsexual persons by the multidisciplinary team $(n=61)$ :

I do not have resources to do the change... the surgery is expensive, more than twenty Thousand ...besides I'm unemployed... I could never do my treatment if it was not for free (e23).

[...] here they know about my situation... they do not keep questioning, putting me up barriers ... All I can do here, I do (e4).

While there is acceptance of the transsexual women by the health professionals, they perceive that this acceptance does not give up on the whole, bearing in mind the pathological vision of the transsexuality $(n=40)$ and configures a difficult factor in the assistance of the Policy of the Transsexualizer Process. 
[...] the doctor (female) treats me very well, the team is marvelous, but do you know that question of waiting for the report of somebody saying what I am because they think that I'm not able to talk for myself? Unnecessary and it only delay the procedure for my surgery (e82).

As a result of the pathologization of the transsexuality, the interviewee women refer other problems experienced by the same in the health care in the Policy of the Transsexualizer Process, such as the delay for the surgery $(n=84)$ and the need for the comprobation of the transsexuality, within the patterns pointed out by the science $(n=62)$ :

I do not know why I have to wait for six years to do the surgery, my time is now ... I have no resources, because if I had, I would have done it long ago. My life is standing: I have problems to relate to other persons, I do not want them to see it (penis)... I cannot change my name in justice... the judges are old and will not see me as a woman while I do not take it (penis) (e44).

For me to have my release card (referring itself to the report for the performance of trans genitalization surgery) I have to convince the team that I'm a woman, as if it was not...(Sigh).(e72)

Most interviewees women mention distress $(n=32)$ and dissatisfaction $(n=56)$ by the delay of the surgery and feel compromised with regard to its full experience as a woman, since the surgical procedure of trans genitalization, making of a neo vagina from the penile tissue, stays in the laudatory dependence on a psychiatrist doctor. For that, the interviewees need to be framed in practices and behaviors considered as feminine, causing discomfort for those who are in inconformity with the determined pattern $(n=13)$.

\section{[...] There are patterns that I do not want to follow and do not make me less woman than women out there (e72).}

The difficulty of attending in other demands of health not implemented by the Transsexualizer Process is referred for more than a half of the transsexual women (57):

When I went to the health office to search for a cardiologist, the persons (health professionals) said that it would be better that I would be attended where I take the hormone. They do not get attending me because it is a differentiated condition (e15).

It is common sense among transsexual women, the discriminatory process by the professionals who do not work in specialized centers and the concern about the health profes- sionals who work in the Policy of the Transsexualizer Process, in the establishment of the diagnosis and emission of a surgical release report in the face of the irreversibility of the same:

I think that they delay to give the opinion because they are afraid of us to regret. After you've started, you cannot go back...but I have no doubt about it [...] (e81).

The health professionals signalized by the interviewees in the specialized center were the physician $(n=56)$, psychologist $(n=13)$ and social worker $(n=25)$. In none speech was the nurse mentioned in the care of the transsexual women.

\section{DISCUSSION}

\section{Science and common sense: interfaces in the assistance to the transsexual and the nursing}

The common sense of the interviewees transsexual does not understand the gender identity as pathology and yes, as a personal, individual true, derived from thoughts and perceptions that should not be correlated with the genitalia. ${ }^{10}$ This thought brought by the transsexual women's needs to be valued by the science, since the same is constructed by problems ${ }^{11}$ emergent from the needs or the situations of discomfort, what does not occur. That the term common sense was created with the aim at minimizing intellectually the value of non-scientific information, which is a great paradox, since the science is the improvement of the common sense. ${ }^{11}$

Even so, the transsexual women's thought is showed as refuted by the social common sense, where there is a set of practices and behaviors constructed that characterize the conditon on being a woman, that begins from the birth, through the definition of the individual by the biological sex. ${ }^{10}$ These differences between the common sense and the science exist in the face of the social position, where an order is established for both of them. However the order produced by the common sense ironically is regarded as an" incongruity", as something not understandable, abstract, different from the understanding of the order brought by the science. ${ }^{11}$

In the health, the conception of gender identity is incorporated and it is evidenced a strong link of the science and the common sense, both in the effort to understand the transsexuality and to search technologies and/or strategies to solve the question of the existing incompatibility mind-body. The science, as an epistemological instrument, in the transsexuality context, was constructed through the attempt to understand the existing phenomenon, to establish the relationship of cause and effect and the development of knowledge and technologies. ${ }^{11}$

However, although present the scientific movement in favor of the assistance to transsexual women, like it is presented by the Policy of the Transsexualizer Process, the scientific edification of the transsexuality does not have as a basis the common sense of the transsexual women and yes, the social hegemonic 
common sense, that interprets as a perversion or something sick the identity incongruity of gender and body, and mediate the unfavorable treatment the interviewees. ${ }^{20-21}$ In this way, it was established, by the scientists, the transsexuality as a process of feeling ill, in a distant perspective of understanding of the identity question as something normal. 10:8

In this sense, the science and technological products derived from them, come to reaffirm the common sense of the society based on the sexual, heterosexual and sexist binarism, where each individual exerts certain functions in the society, with regard to the sex at birth. The science is used as a regulatory tool of the order that is founded on the human species conservation. ${ }^{11}$ While there is satisfaction of the transsexual women in the creation of technologies to feminize the body, until then masculine, they occur under form of perpetuating a dichotomous normative model. This ideal body is supported by the science that conceives the need to establish patterns to the bodies, in the health context. ${ }^{22}$

A scientific order then, is created, from the reading of the social common sense, that perpetuates the norms of gender and acommodate the transsexual women to these idealized patterns, according to the thought of Alves that said that the scientific knowledge has as objective the modification of the individual. ${ }^{11}$ For that, the science forms and deforms codes, a result of the culture in that permeates, and dispose of a disciplined control, a kind of a driver guide for its actions, from the scientific knowledge acquired. ${ }^{11}$

This scientific thought reflects on the care model controller and discipliner of bodies developed by the Transsexualizer Process in face of the established social patterns, and brings rigidity to the care practice. Such health policy does not get looking at the transsexual persons in a natural way, as well as the cisgender women, born biologically with female sex. In a cyclical event, echoes to the health professionals, who do not question the binary normativity. ${ }^{23 ; 8}$ This event is a demonstration that the science use its improved knowledge in a regulatory way, reinforces and demarcates a strong relation of power of those who are entitled as representatives of the science on those who are entitled as the study object of the same..$^{1 ; 1}$ Analogically the medicine, as a representative of the science, does not refute the binary naturalness with solid scientific evidences. ${ }^{3}$

The common sense of transsexual women, about the feasibility of the physical changes in the Transsexualizer Process, was present with notoriety. The common sense arose from practical, operational questions, ${ }^{11}$ emanated from the needs for physical adequacy of the interviewees. Their needs do not contradict the social norms and end up to attend a social normative and reconciles with the common sense and with the science that aim at the order. ${ }^{11}$ Realizing the physical re adequacy, both for the physical feminization via hormonotherapy, and for the penile and scrotal surgical reconstruction for making a neo vagina, entitled trans genitalization surgery, report, equally to transsexual women and to the society, the satisfaction of a binary order of gender.
For implementing the order of the common sense of physical adequacy through the policy of the transsexualizer process, the science, as a technology, produced knowledge, methods and products that would provide a process of practices transformation and contemplation. ${ }^{22}$ Even so they are insufficient and bring the need for remodeling of the care process. There are no reports of movement of health professionals to change the scenario with regard to the resolution of the dissatisfactions presented by transsexual women, that agreed with the idea of Alves that the science, as a reference that dictates knowledge and practices and ends up promoting an inhibition of the thought, ${ }^{11}$ in the case of the health professionals, for the identification and the need for recreating and/or reformulating of new care strategies.

Such strategies should cover the demands of care to the promotion of health of transsexual population, being developed and or improved by the health professionals in all stages of transition, in order to break the immobility of studies that subsidize the practice, including the one of the nursing that should be faced with priority by the profession. ${ }^{24}$

The need to seek technological solutions, as well as the improvement of techniques and the re-orientation of the care model, should come from the demands of the common sense arisen from transsexual women in order to go along with Alves defines as the "right things" with the "desired effects". ${ }^{11: 13}$

In that way, the existence of an epistemologically deficient care model about transsexuality is not only achieved in face of the ideological and assistance format drawn up by the Policy of the Transsexualizer Process and may have been decisive in the interviewees' narratives about the difficulty of fulfilment the demands of health in other health services. The science, through a group that thinks about a knowledge, represented by the specialized centers in the policy of transsexualizer process, exempts other groups from thinking about the matter. ${ }^{11}$

In order to resolve this dissent and operationalize the care to transsexual woman in an effective way in the other segments of health services provided, specialized or not, it's necessary the dialogical action among the health professionals in all levels of attention, since the vision of the individual about an object is individual and not only is in accord with others individuals that had contact with the same object. ${ }^{2}$ That is, the continuous look, acquainted and common upon the trans women in the specialized centers is different from the look in other segments of health and is reflected in difficulties at the moment of the search for care in the same.

The look upon the object in the health units that do not provide specialized care in the transsexualizer process is discriminatory, bearing in view the ideological character of abjection, perversion or disorder that the professionals have on these users. ${ }^{3}$ It can be a result of the lack of information, since, according to Alves is an instrument for the action. ${ }^{11}$ That way, the scientific construct must be disseminated for all the health professionals who work in the specialized center or not, so that all the health system is able to understand the dynamics in the objective context and attend the users' desires. 
It is presupposed that there are care failures in the basic attention, bearing in mind that the referral to other segments of health is arisen from the same, considered as front door to several services in health and the specialized centers. In this case it is thought that according to Alves the thought must be turned to the similarities and not to the differences, that is, although the levels of complexity are distinct, there is a similarity with regard to the tipycity of the assisted population. ${ }^{11}$ In this case, transsexual women should be accessibility to the qualified attendance and deprived of discrimination, in the specialized centers or in other demands in health that are not linked directly to the process of physical transition, and find it in the basic attention. The nurse is one of the operating professionals in this process and has an important role in the development and organization of strategies and actions based in the population to be attended. ${ }^{25}$

The Policy of the Transsexualizer Process, composed of a group of health professionals that aggregates specific knowledge, do not have adequate knowledge to provide care according to the thinking of transsexual women. Study carried out by the Faculty of Nursing of the University of Nebraska revealed that the nursing does not have significant knowledge or specialty to address the demand brought by this clientele that affects the quality of care provided. ${ }^{24}$

The science, applied in the Policy of the Transsexualizer Process, is a specialization, ${ }^{11}$ with technical and scientific deepening in the feminization of transsexual women, but it does not get fully exploiting the health professionals, since the nonallusion to the common sense and consequent partiality in the understanding and presentation of solutions to problems.

It is common sense among the interviewed transsexual women, the delay for carrying out the surgery through the Transsexualizer Process, which occurs in general after the certification of the transsexuality by the health professionals. Such fact occurs because the scientific knowledge puts power in the hands of who produce or reproduce the knowledge. ${ }^{1}$ The scientist, as a representative of the science and as an instrument of knowledge, has a speech that must be heard and embraced. Here, scientists are considered the producers of the Policy of the Transsexualizer Process. ${ }^{11}$

The proof of the transsexuality for surgical release is carried out from the search for pre-established patterns by the health professionals, provided by the science. In this scenario, the knowledge is built through a "scientific meta-language" that determines rules which delimit the correct possibilities to be implemented, ${ }^{1: 4,13}$ based on the image of an idealized body..$^{22}$

This specific language has its understanding based on built and tested hypotheses ${ }^{11}$ on the need to define diagnosis from symptoms, as it was a woven weft, as it had an ideal plan. ${ }^{11}$ The scientists that projected the Transsexualizer Process did not perceive that used the social knowledge to determine the diagnosis based on stereotypes, such as long hair for girls and short hair for boys. ${ }^{26}$ In this case this Health Policy, as a product of a construction ordered of knowledge by science, assumes a weakened dress on the understanding of the feminine identities, bearing in mind the normative character, rooted of social stereotypes, behind the changes arising from the historical trajectory faced by transsexual persons. ${ }^{23 ; 26}$

The transsexual woman, to be submitted to the medicalization process, in the Policy of the Transsexualizer Process, eliminate any non-normative experience and ideological thought to follow a medical code that limits the true about the transsexuality, as a pre-requisite to enjoy the hormonal and surgical tools..$^{23: 241}$ This occurs because the science is understood as an improvement of areas and brings with it the domain and authority over the same. ${ }^{11}$

However, the judgement of taste of transsexual women is an independent question and should not have a rigid format, in the face of an idealized object. Each individual is the representation of what it is, of its essence. As a judge of a matter of its own body and opinion, the persons should stick to essentialist concerns and ignore the object which refers as the ideal, ${ }^{22}$ that in the event, does not occur with transsexual women.

The codes implemented by the science in the face of the aesthetic issue, even that they are the representativeness of the true, they show that the same is able to improve or understand the issue of the look of the transsexual users, for not holding learning about the plurality of the feminine identities, ${ }^{27-28}$ only being possible to acquire some knowledge from the findings identified in the same. ${ }^{11}$

For such, the health professionals should make use of the support science, capable of generating learning from the common sense of the transsexual women, solidifying knowledge, and developing individualized attendance and convergent to the needs of the category. The science should be used as a tool capable of bringing new perspectives in the epistemological process of the transsexuality, since for Alves it should be innovation, even that they had drawn conclusions about a certain problem. ${ }^{11}$

In the results it is affirmed by the interviews the acceptance of transsexual women by the health professionals, but in a pathological and stereotyped bias. In the categorization process, considering the non-said in the narratives, ${ }^{28}$ the nursing was not mentioned in the care to transsexual women. This condition of invisibility is worrying, since the nursing is included, by the Policy of the Transsexualizer Process, as a member of the multidisciplinary health team. ${ }^{6}$ This non-said, that is, the nondescribed in the narratives, denotes a silent nursing, ${ }^{30}$ that may contribute to the misunderstanding of transsexual persons regarding their specific health demands $\mathrm{s}^{8 ; 31-32}$ and compromise the quality of the nurse's care. Authors refer that the nursing does not have significant knowledge or specialists readily accessible and available for the attendance to transsexual persons and that this compromises the quality of their care. ${ }^{24}$

There is a need for nursing to become visible, present an active hearing of the desires and grasp the information provided by users, which the science understands as common sense, in order to promote a respectful and inclusive care to the demands presented. ${ }^{28}$ These information should be offered to the scientific 
community in order to validate them and enable epistemological constructions that qualify the nursing care to this clientele. This constitutes a great challenge for the nursing before the existing gaps in the professional training about the transsexual women's health. ${ }^{30-31}$ The science is an instrument for the construction of this knowledge, through the investigation and elaboration of solutions to be counted from the common sense, in enabling the nursing to make reflections about the professional practice..$^{14}$

According to the data presented above, it could be said that the philosophy of science is aligned to the idea of production and detention of knowledge, providing them with the right instruments and ordering the practice, even the health. ${ }^{9}$ This is also a validated and improved product of the common sense, which determines the need to know the common sense to implement a real science, that provide consistent information for the health practice and in it the one of nursing. ${ }^{9 ; 14}$

It could be said that the epistemological construction of the transsexuality, at the level of science, does not make use of the common sense of transsexual women and yes of the common sense of the society, which weakens the qualified care to users and makes it difficult the non-stereotyped and pathological look, by the health professionals.

A paradox is established with regard to the use of the science in assisting transsexual women, since at the same time that is a facilitator in the physical transition process, is not fully coherent with the desires of the same, what can be dangerous . ${ }^{11}$ Such fact was evidenced in the study, when the science does not address the thinking of the transsexual women. The science, with its scientists, developed the attendance by the policy of the transsexualizer process medicalized and with stereotyped thinking of femininity. However, this same science provided an opportunity of technologies that favored the transition of the transsexual women. Then it is thought that the science can converge for the interests of the transsexual women, of health professionals and all who belong to the care scenario of these women, provided that well focused on the common sense of this group.

Understanding epistemologically the transsexuality from the common sense of transsexual women, of the science and of the nursing is important to identify the relationship among them that does not occur in a satisfactory way. The science, which has as role the affirmation and construction of knowledge, as, for instance, the care given for the nursing in the Policy of the transsexualizer Process, but it does not do well, since the non-use of the common sense in the construction of the knowledge. ${ }^{32}$ It's necessary the inclusion of the common sense of the transsexual women by the science, so that the same is able to offer subsidies for the mastery of the nursing practice to users.

\section{CONCLUSION}

The knowledge about the common sense of the transsexual women revealed the non-pathological vision about the transsexuality and care problems, such as the delay for releasing the reports to carry out the surgery of sexual redesignation. Although they understand the attendance by the Policy of the Transsexualizer Process and the acceptance by the multidisciplinary team as benefit, remains the discomfort of the requirement of a pattern established by the science as a requisite for the condition of transsexual woman for the health professionals.

The pathologization of the transsexuality and the delay in the carrying out of surgical interventions for the physical transition were pointed out as the main problems presented by the transsexual women, in the Policy of the Transsexualizer Process. The science, which instrumentalized this policy does not have any knowledge that addresses the true needs of the transsexual women and is distant from the refinement of the common sense.

Other problem found was regarding the nurse (female), professional of the Policy of the transsexualizer Process, not mentioned in transsexual women's narratives. The nursing needs to understand the questions related to the transsexuality, being instrument of articulation of the common sense as scientific knowledge and the common sense.

The science for the epistemological construction of the transsexuality does not make use of the common sense of the transsexual women and weaken the care process, strengthen the stereotypical and pathological character used to the same, by the health professionals.

\section{REFERENCES}

1. Adinolfi VTS. Discurso científico, poder e verdade. Revista Aulas [Internet]. 2015;1(3):1-10. Disponível em: http://www.ifch.unicamp.br/ ojs/index.php/aulas/article/download/1940/1401

2. Fonseca RMGS, Souza KV, Andrade CJM, Amaral MA, Souza V, Caetano LC. Creation of a nursing research group on women's health and gender. Texto Contexto - Enferm [Internet]. 2012 oct;21(4):990-998. Disponível em: http://www.scielo.br/pdf/tce/v21n4/en_32.pdf

3. Cunha EL. O homem e suas fronteiras: uma leitura crítica do uso contemporâneo da categoria de perversão. Ágora (Rio J) [periódico na internet]. 2016 jan/abr;19(1):85-101. Disponível em: https://dx.doi. org/10.1590/S1516-14982016000100006 DOI: 10.1590/S151614982016000100006

4. Araujo LM, Penna LHG. A relação entre sexo, identidades sexual e de gênero no campo da saúde da mulher. Rev Enferm UERJ [Internet] 2014 jan/fev;22(1):134-8. Disponível em: http://www.facenf.uerj.br/ v22n1/v22n1a21.pdf

5. Bento BAM. O que é transexualidade?. São Paulo: Brasiliense; 2008.

6. Portaria n. 2.803 de 19 de novembro de 2013 (BR). Redefine e amplia o processo transexualizador no sistema único de saúde (SUS). Diário Oficial da União, Brasília (DF), 19 nov 2013: Seção 1. Disponível em: http://bvsms.saude.gov.br/bvs/saudelegis/gm/2013/ prt2803_19_11_2013.html

7. Cordero MB, Ramírez JM. Los servicios de apoyo a las personas transgénero: una realidad imperceptible. Revista Griot [Internet]. 2015 dec;8(1):73-84. Disponível em: https://dire.upr.edu/ bitstream/handle/11721/1047/Vol.8-No.1-2015-p.73-84\%20Griot. pdf? sequence $=1$ \&isAllowed $=y$

8. Janini J, Santos RS, Vargens OMC, Araújo LM. A medicalização e patologização na perspectiva das mulheres transexuais: acessibilidade ou exclusão social. Rev Enf UERJ [Internet]. Ano;v(n):p. Disponível em: DOI: http://dx.doi.org/10.12957/reuerj.2017.29009

9. Silva AM, Silva AVA, Clementino MCM, Garbaccio JL. O olhar da enfermagem na assistência à pessoas trans (T3). Enfermagem Revista [Internet]. 2019 jan; [access in 2019 mar 02]; 21(3):85-105. Disponíve em: http://periodicos.pucminas.br/index.php/enfermagemrevista/article/ view/19325 
10. Ferraz CV, Leite GS. A Desconstrução da relevância jurídica do sexo biológico em face da identidade de gênero na transexualidade: a tutela jurídica da mulher transgênero. Conpedi Law Review [Internet]. 2016;1(1):67-87. Disponível em: http://portaltutor.com/index.php/ conpedireview_old/article/view/14/16

11. Alves R. Filosofia da Ciência: introdução ao jogo e a suas regras. $19^{a}$ ed. São Paulo (SP): Edições Loyola; 2015.

12. Petry AR. Mulheres transexuais e o Processo Transexualizador: experiências de sujeição, padecimento e prazer na adequação do corpo. Rev Gaúcha Enferm [Internet]. 2015 jun;36(2):7075. Disponível em: http://www.scielo.br/scielo.php?script=sci arttext\&lng=pt\&tlng=pt\&pid=S1983-14472015000200070http://dx.doi. org/10.1590/1983-1447.2015.02.50158

13. Foucault M. Verdade e Poder. In: Foucault M. Microfísica do Poder. Rio de Janeiro (RJ): Edições Graal; 2004.

14. Araujo RA, et al. Contribuições da filosofia para a pesquisa em enfermagem. Esc Anna Nery [Internet]. 2012 jun;16(2):388-394. Disponível em: http://www.scielo.br/scielo.php?script=sci_arttext\&pid=S1414$81452012000200025 \&$ Ing=en\&nrm=iso DOI: $10.1590 /$ S141481452012000200025

15. De Jesus JG, Alves $H$. Feminismo transgênero e movimentos de mulheres transexuais. Revista Cronos. 2012 nov;11(2).

16. Conselho Nacional de Saúde - CNS (BR). Resolução no 466, de 12 de dezembro de 2012. Diário Oficial da União, Brasília (DF): Ministério da Saúde. 12 dez 2012; [acesso em 2018 jan 04]. Disponível em: http:// www.conselho.saude.gov.br/web_comissoes/conep/index.html

17. Johnston LG. Sampling methods for measuring TB stigma in hard-toreach populations without sampling frames. In: Mitchell EMH, van Den Hof S. TB Stigma Measurement Guidance [Internet]. The United States Agency for International Development (USAID): Challenge TB; 2018. p.184-211. Disponível em: https://www.challengetb.org/publications/ tools/ua/TB_Stigma_Measurement_Guidance.pdf\#page $=185$

18. Sharma G. Pros and cons of different sampling techniques. International Journal of Applied Research [Internet]. 2017;3(7):749-52. Disponível em: http://www.allresearchjournal.com/archives/2017/vol3issue7/ PartK/3-7-69-542.pdf

19. Minayo MCS, organizadora. Pesquisa social: teoria, método e criatividade. 34 ${ }^{a}$ ed. Petrópolis (RJ): Vozes; 2015.

20. Van Borm $\mathrm{H}$, Baert $\mathrm{S}$. What drives hiring discrimination against transgenders?. International Journal of Manpower. 2018 jul;39(4):58199. Disponível em: https://doi.org/10.1108/lJM-09-2017-0233

21. Singh GD. Transgender and Their Social-Legal Status: An Empirical study in State of UP [dissertation]. India (Agra): Ambedkar University; 2015.
22. Baptista TJR, da Silva Zanolla SR. Corpo, estética e ideologia: um diálogo com a ideia de beleza natural. Movimento. 2016 jul/ set;22(3):999-1010.

23. Eckhert E. A Case for the Demedicalization of Queer Bodies. Yale J Bio Med [Internet]. 2016 jun;89(2):239-46. Disponível em: https://www.ncbi. nlm.nih.gov/pubmed/27354849

24. Paradiso C, Lally RM. Nurse Practitioner Knowledge, Attitudes, and Beliefs When Caring for Transgender People. Transgender Health [Internet]. 2018 dec;3(1):47-56. Disponível em: https://doi.org/10.1089/ trgh.2017.0048

25. Soder R, Oliveira IC, da Silva LA, Santos JL, Peiter CC, Erdmann AL. Desafios da gestão do cuidado na atenção básica: perspectiva da equipe de enfermagem. Enfermagem em Foco [Internet]. 2018 nov;9(3) Disponível em: http://revista.cofen.gov.br/index.php/enfermagem/ article/view/1496

26. Natt ED, Pádua CA. É para menino ou para menina? Representações de masculinidade e feminilidade. Revista Latino-Am Geografia e Gênero [Internet]. 2016 jan;7(1):109-31. Disponível em: DOI: 10.5212/ Rlagg.v.7.i1.0008

27. Haines EL, Deaux K, Lofaro N. The Times They Are a-Changing... or Are They Not? A Comparison of Gender Stereotypes, 1983-2014. Psychology of Women Quarterly [Internet]. 2016 mar;40(3):353-63. Disponível em: https://doi.org/10.1177/0361684316634081

28. Eagly AH, Wood W. Social Role Theory of Sex Differences. The Wiley Blackwell Encyclopedia of Gender and Sexuality Studies. In: Naples NA, Hoogland RC, Wickramasinghe M, Wong WC, organizers. The Wiley Blackwell Encyclopedia of Gender and Sexuality Studies [Internet]. Hoboken:Wiley Blackwell; 2016. p.1-3. Disponível em: https://doi. org/10.1002/9781118663219.wbegss 183

29. Sutton J, Austin Z. Qualitative research: data collection, analysis, and management. Can J Hosp Pharm [Internet]. 2015 may/jun;68(3):22631. Disponível em: https://www.ncbi.nlm.nih.gov/pmc/articles/ PMC4485510/

30. Silva OSF. Os ditos e os não-ditos do discurso: movimentos de sentidos por entre os implícitos da linguagem. Revista entreideias: educação, cultura e sociedade. $2009 \mathrm{jul} / \mathrm{dez} ; 1$ (14):39-53.

31. Manzer D, O'Sullivan LF, Doucet S. Myths, misunderstandings, and missing information: Experiences of nurse practitioners providing primary care to lesbian, gay, bisexual, and transgender patients. The Canadian Journal of Human Sexuality [Internet]. 2018 aug;27(2):157170. Disponível em: DOI: $10.3138 / c j h s .2018-0017$

32. Dahnke MD, Dreher HM. Philosophy of science for nursing practice: Concepts and application. $2^{2}$ ed. United Estates: Springer Publishing Company; 2015. 